\begin{tabular}{ll}
\hline 論 & 説 \\
\hline
\end{tabular}

\title{
口腔内疾患の取扱
}

\author{
設 楽 哲 也
}

\section{Management of Diseases of the Oral Cavity}

Tetsya Shitara

(Kitasato University)

Adequate medical treatment of malignant tumors in the oral cavity is most important in the management of otorhinolaryngological diseases.

The methods of treatment in current use are laser therapy, irradiation, total removal of the tumor by surgery, reconstructive operation, chemotherapy, immunological approach and various combinations of these.

"Five year cure-rates" with these procedures are better than in the past, but it is necessary to promote both early diagnosis and early treatment to gain much better results.

Otolaryngologists play the most important role in the management of malignant tumors of the oral cavity, and they should be responsible for both earlier diagnosis and earlier therapy. Therefore, all otolaryngologists should know about all the diseases of the oral cavity.

Key words : malignant tumors in the oral cavity, management, earlier diagnosis, earlier therapy

\section{はじめに}

口腔内疾患は耳鼻咽喉科以外に皮膚科，また 歯科関係では歯科, 口腔外科が扱っている.

疾患によって扱う科が違うのであるが, 耳鼻 科では何を診るのが適切かは一度整理して眺め る必要がある。乙れには患者の立場に立って, 特に治療の立場から見るのが良い.たとえば全 身性疾患の一部としての口腔内病変は内科に紹 介する事が必要であろうし, 皮膚科が治療を得 意とする領域も多い，歯科の領域屯多い事む否 定しない。形成の领域もある.

耳鼻科の領域であるとして譲るととが出来な
いのは悪性腫瘍である. 全身疾患であり, 手術 を要するからである，治療上悪性腫焬が耳鼻咽 喉科が最適だとすると, 診断も耳鼻咽喉科がお ろそかにする事が出来なくなる. 現在であ外科 内科を経て口腔内の悪性腫瘍が送られてくる事 が多く，乙の事は大変有難いてとである. 実地 医家である耳鼻咽喉科医師からも勿論送られて くるが, 地域によってはての比率は必ずしも高 くないように見える.

医療の目的は最終的には治療であり，診断は 治療のための一段階である. 診断学は常に治療 を意識して成立っているのであって，詪断に当 
り考慮することは，まずは救急疾患であるの か，伝染性疾患であるのかである，ての 2 つは 可能性があれば直ちに近在の適切な施設に紹介 することは言うまでもない.

悪性腫瘍は治療成績の悪い遠い過去において は救急的な扱いをする必要が少なかったのであ るが，現在の様に良く治るようになり，しかむ 治癒率が発見から治療までの期間に掛っている のではその扱いは準救急である.

この事は勿論口腔疾患に限ったととではなく 鼻腔副鼻腔, 咽頭喉頭, 耳下腺, 顎下腺, 下咽 頭, 甲状腺, 耳など全ての頭頸部悪性腫煬に共 通なことである。

治療を行なっている側としては，一番の診断 空口である実地医家の耳鼻咽喉科医に積極的な 口腔疾患の取組みと, 準救急的な取扱での治療 施設への紹介をこの機会に御願いしたいのであ る.

悪性腫瘍は組織検查をする段階で治療方針を 決めて行なう必要があり，医師のむとに受診し てから治療迄の日数とその間の取扱が治療成績 を決するのである，耳鼻咽喉科医師が診断と治 療に関係しててそ，乙の間の一連の動きが可能 となるのである，㓜論内科外科の医師にもての 事を要望したい.

\section{悪性腫瘍の治療率向上について}

a ）治瘾率向_上の第一は早期発見である. 同 時に早期治療開始である。

b ）全身の管理を行なうことである.

c ）レーザー手術，放射線手術，外科的手 術, 化学治療の組合せが自由に出来る事であ る.

以上のうち b )，c）に関して怆大学病院， 大病院の耳鼻咽喉科が適切な科であるととは言 うまでもないが，a）に関してはいまだ充分な 体制とはいえず改良する余地があるように思え る. との事がこの論文の主旨である.

すでに述べたように悪性腫瘍に関しては発見 すれば治療施設に送るととはおそらくどてでも 行なっているととであろうが，確実に一目で悪
性腫愓之判定できるものは問題がないが，判定 の比較的に難しいものでは治療施設に送ること が遅れる可能性がある．確認してから送りたい ために組織を採りたくなるであろうし，悪性腫 瘍でない場合の治療, 例えば副腎皮質ホルモ ン，抗生物質等の投与を試みたくなるであろ

う. しかし悪性腫瘍を早期に治療するために は，その類似疾患む，場合によると口腔咨患全 ての空口であるとととともに，怪しきものは治 療できる耳鼻咽喉科に早期に送ることが必要で ある。

ての事を組織的に考えてみると，治療を行な う大学ないし大病院の耳鼻咽喉科の, 診断に関 しての大きな空口であるその地域の耳鼻咽喉科 の診療所が，口腔内疾患の空口としての一次診 療の場であるかという事がまず大切で，乙机に はこの地域の一般の人々が口腔の悪性腫煌の治 療は耳鼻咽喉科が最適だと知っているかどう か, 内科, 外科のどの程度の医師がこの事を承 知しているかどうかにも掛っている.

この事の解決は，一つには耳鼻咽喉科の科名 に口腔の文字がないととにもより，口腔咽頭科 の科名申請, 学会設立などの必要性もあるが, 第一には日常診療で今よりも一層積極的に扱う こと, 診断之治療の, 特に悪性腫瘍に関して大 学病院, 大病院と実地医家との間のチームプレ イを良くすることが必要である.

従来そのようにあったはずであるが，耳鼻科 医は口腔内疾患全体にわたる知識が必要であ る.このととは上記したように悪性腫煌が良く 治るようになった今日，治療に対する責任は耳 鼻咽喉科が最屯大きいとの自覚をむっている以 上診断の空口としての責任もあるてとは避りら れないからである。

耳鼻咽喉科の実地医家はいわば振分け外来的 な作業を行なう必要がある．振分け外来の作業 の要点は, 診療科の振分け之救急疾患の振分け である。

\section{口腔疾患診断の注意点}

以下に振分け外来としての疾病の分類を掲げ 
る.

a) 放置してよいむの：フォアダイス状態, 舌扁桃（舌根扁頭ではない，正中菱形舌炎, 地図状舌, 口蓋隆起.

以上の疾患は治療を要さないものなのである ことを確認し, 視覚的にその所見をしっかりと 記憶しておく必要がある.

b ）大学の耳鼻咽喉科紹介の病変 : 腫瘍性疾 患, その弁別困難なもの, 手術的に治療するも の (後述).

c）皮膚科, 内科, 小坚科紹介のあの：全身 病の部分症状としての口腔疾患を中心に.

膠原病, 水疱症, 紫斑, 薬疹, 母孩色素異 常, 内分泌代謝異常, ベーチェット病, 麻疹, 水痘.

d）歯科紹介のもの：歯に原因のある炎症性 疾患.

e ）耳鼻科実地医家専門医の治療範囲のもの : アフタ性疾患 (ベーチェット病との鑑別), ヘルパンギーナ, 単純疮跨. 簡単な手術で済む 小唾液腺粘液囊腫，がま腫など.

実地医家で口腔疾患で多く見るものとして， 舌の痛み, 乾燥感, 味覚障害がある。これらの

表 1 口腔内疾患の男女別発生頻度 (治療例のみ)

\begin{tabular}{l|r}
\hline \multicolumn{1}{c|}{ 患 名 } & 症例数(女) \\
\hline 小唾液腺粘液囊腫 & $68(47)$ \\
ガマ腫 & $40(31)$ \\
扁平上皮の增殖・角化 & $69(39)$ \\
線維形成性疾患 & $39(23)$ \\
化膿性肉芽腫 & $35(24)$ \\
炎症, 潰瘍, 肉芽等 & $61(30)$ \\
血管, リンパ管腫 & $16(7)$ \\
多形腺腫 & $12(6)$ \\
歯根囊腫 & $12(7)$ \\
皮様囊腫 & $7(4)$ \\
正中口蓋囊腫 & $4(2)$ \\
シェーグレン病 & $9(9)$ \\
稀な良性腫瘍 & $6(2)$ \\
その他 & $6(3)$ \\
癌 & $73(22)$
\end{tabular}

主訴に対する取扱に関しては高齢者の増加とと 屯に重要となり，乙れから設立される口腔咽頭 学会に大いに期待する所である。

表 1 に大学病院耳鼻咽喉科で扱う疾患として 北里大学耳鼻咽喉科の手術症例の統計 ${ }^{2)}$ を示す (昭和 46 年 7 月から昭和 60 年 3 月まで)，総数は 457 名であるが，乙の数は手術ないし放射線治 療総数であり, アフタ等の薬物治療例, すでに 述べた放置して良い例，他科沼介した紹介を除 いた数である。乙れを加えれば，耳鼻科で診療 した口腔疾患総数はむっと大きいのであるが， その数は㨔めない.

口腔癌は73例であり, 手術を行なった口腔内 疾患の $16 \%$ である。口腔癌の頭頸部癌の中で占 める数は, 癌研, 癌センタ一, 神戸大学耳鼻咽 喉科の上顎癌, 喉頭癌, 口腔癌の比較を見ると （3施設の合計）口腔癌は上䪽癌よりもはるか に多く, 喉頭癌よりもやや多いか, ほぼ同数で ある1． 前癌状態である白板症の存在を考えれ ば口腔疾患の耳鼻咽喉科で占める位置は高い。

\section{口腔悪性腫瘍の治療の進歩}

悪性腫瘍の治療は抗癌製剂の進歩に負う所が 大きいが，頭頸部領域，中でも口腔癌に関して はレーザー治療の恩惠を大いに蒙っている．ま た皮膚筋弁による再建手術も拡大腫瘍手術の可 能性を大きくしている。

a）口腔癌のレーザー治療

我々が若い時代には舌癌の治療は, 範囲が狭 ければラジウム針であり，範囲の広いものは下 顎切断を伴うコマンド手術であった。 ラジゥム 針は放射線取扱の面で, 特殊な場所でないと行 なわれず，不満足ながら遠隔照射が行なわれて いた．ラジゥム針治療は今でも素晴らしい成績 を示しているが7)，特殊な施設でない限り，冷 凍手術，超音波メス，レーザー手術が行なわれ るようになり，最近ではレーザー手術が良く使 用されている，組織の回復が早い点，手術創転 移が起こりにくいなどの利点があり ${ }^{8) 91}$, 今後 益々利用されよう。難点は手軽なために安易に 行なわれるととを警戒することであって，癌の 
広がりを充分に考慮するととと再発時の対策を 立てて执くことが大切である。レーザー治療は 舌癌以外の口腔癌の何れもが対象になり，また 前癌状態, 癌と鑑別を要するもの, 良性腫瘍と くに血管腫, 口唇粘液囊胞")などにも有効であ る.

b ）再建手術の進歩

頭頸部癌の再建手術はD P 皮弁の手法がはじ まりである．乙の手法により広範囲切除が可能 となったが，口腔癌に関しては筋皮弁の手法に 負う所が大きい. この特徵は一次的再建が可能 なとと, 術後の舌の運動等の機能が保存しやす いなどの特徵がある゙ ${ }^{9) 10}$.

c ）抗癌剂の進歩屯忘机ることが出来ない.

私の若い時代には抗癌剂は有効かどうかの判 定が出来なかったが，最近では延命効果は確実 にあるとの考え方で治療が行なわれている.

進行例で手術拒否者に対して行なわれた放射 線療法, 抗癌剂療法, 局麻で行なう程度の簡単 な手術でも 2 年以上のコントロールが可能であ $ろ^{11)}$.

以上述べたような治療, あるいはこれらの組 合せによって，口腔癌の治療成績は向上した が, しかし癌発見は早ければ早い才が良く, 癌 の治療は発見から出来るだけ早く行なった方が 良い。またての余地はまだ大きく残されてい る. この余地を埋めるととによってさらに治療 効果を高めることが出来よう.

癌の広がりが小さければ機能を残して根治可 能であり, 成績も良いのは当然である. 進行例

表 2 口腔癌の発生部位と頻度 ${ }^{2)}$ (北里大)

\begin{tabular}{ccc|c}
\hline 部 & \multicolumn{2}{c|}{ 位 } & 症例数(女) \\
\hline 煩 & 粘 & 膜 & $7(2)$ \\
下 & 柬 & 肉 & $4(1)$ \\
口 & & 蓋 & $9(2)$ \\
舌 & & 縁 & $47(17)$ \\
舌 & & 下 & $4(0)$ \\
口 & 腔 & 底 & $2(0)$
\end{tabular}

でも治療は出来るだけ早くはじめた方が良い (表 2 ).

\section{各種疾患の取扱}

\section{a ）口腔癌}

表 2 に北里大耳鼻科に於ける14年間の口腔癌 患者数とその部位別頻度を示す. 表 1 の続きで ある。

この症例の多くは耳鼻咽喉科と内科, 外科よ り紹介されていて, 組織片は採取されていな い. この事は大切なことであって，転移しやす い扁平上皮癌, 悪性リンパ腫に於いては組織切 片採取後出来るだけ早く, 可能ならば治療計画 は勿論, 放射線治療, 抗癌剂治療を先行してか ら組織切片を採取するぐらいの配慮すら必要で ある.レーザー手術の役割は大きい，放射線治 療, 抗癌剂治療, 搪大手術に於ける再建手術の 進歩も目覚しいものがある。しかし，転移しや すい悪性腫瘍なので，全身のチェックを心掛け なければならない。

b ）白板症に対する考え方

この内のかなりの症例は前癌状態であるか, 将来そうなり得るので注意を要する ${ }^{6)}$. 経過を 見て症状の変化を見たら治療施設に紹介を要す るが，一度は紹介して組織を調べる力が良いと の見解がある．経過をみずに放置するのは良く ない，治療はレーザーが有効であるが，完治が 難しい例がある5).

c ）物理的刺激による潰瘍

好発部位が癌と同様であるので，鑑別は難し い. 視診触診の経験を積む必要があるが，例え ば義歯の影響と簡単に定めずに悪性腫瘍の治療 が出来る病院の耳鼻咽喉科に紹介することを勧 めたい，義歯等の影㗽かどうかはそてで決定す れば良いのである。

d）アフタ性病変

再発性のもの, ベーチェットがあるがその鑑 別は所見からは不可能である゙ ${ }^{3)}$ 治りにくいも の, 再発を繰返すむのはべーチェットを疑う必 要があり, 可能性が強ければ皮膚科, 症状によ っては内科に紹介することである。 


\section{まとめ}

口腔内悪性腫瘍は手術と全身管理の可能なと とから耳鼻咽喉科が治療するのが最適であり， 治療成績を向上させる責任がある，診断治療の 地域ごとのチームを作る必要がある。口腔内疾 患の振り分け外来を行なうためには疾患全てに 関する知識が必要である.

この論文の主旨は第87回日本耳鼻咽喉科学会総会の パネル “口腔疾患の診断と治療の進歩”に述べた事で あり，その論文集 JOHNS 6 巻より多くの引用をし た。

\section{参考文献}

1）設楽哲也：口腔内疾患の診断と治療のててろがま え. JOHNS 6:603〜604, 1986.

2 ) 高橋広臣, 岡本牧人, 八尾和雄, 他: 口腔内疾患 の統計的観察. JOHNS 6:605 609, 1986.

3 ）古内一郎, 馬場廣太郎, 島田 均, 他: 再発性潰 瘍による下咽頭狭窄例一再発性アフ夕に対する治 療法一. JOHNS 6:621〜625, 1986.
4）法貴 昭，増田基子，山辺けい子：ラヌラおよび 下口唇粘液囊胞の治療. JOHNS $6: 627 \sim 632$, 1986.

5 ）法貴 昭, 増田基子, 山辺けい子：白斑症（白板 症）について. JOHNS 6:651〜655, 1986.

6) 井上哲生, 内田正興, 坂本穆彦, 他: 長期観察例 から見た口腔白板症の予後. JOHNS $6: 657$ $661,1986$.

7 ) 鎌田信悦. 舌癌の治療方針の検討一特に放射線治 療と手術の適応について. JOHNS 6:669 $673,1986$.

8 ）法貴 昭, 石田春彦, 増田基子, 他：舌癌のレ一 ザーによる治療. JOHNS 6：675〜 678， 1986.

9 ) 岡本牧人, 高橋広臣, 八尾和雄, 他: 手術治療を 中心とした口腔悪性腫煌の治療. JOHNS 6 ： 679 684, 1986.

10）内田正興：口腔癌治療における再建外科の現況. JOHNS $6: 685 \sim 690,1986$.

11）高橋広臣, 岡本牧人, 八尾和雄：舌癌の保存療 法. JOHNS $6: 691 \sim 694,1986$.

別刷請求先：設楽哲也

干228 神奈川県相模原市北里 1 丁目 15-1

北里大学医学部耳鼻咽喉科学教室 